\title{
Mutagenicity and genotoxicity of suspended particulate matter in the Seine river estuary
}

\author{
Françoise Vincent-Hubert ${ }^{\mathrm{a},{ }^{*}}$, Karine Heas-Moisan ${ }^{\mathrm{b}}$, Catherine Munschy $^{\mathrm{b}}$, Jacek Tronczynski ${ }^{\mathrm{b}}$ \\ a Département Biogéochimie et Ecotoxicologie, Laboratoire d'écotoxicologie, IFREMER, 44311 Nantes cedex, \\ b Département Biogéochimie et Ecotoxicologie, Laboratoire de Biogéochimie des Contaminants Organiques, \\ IFREMER, 44311 Nantes cedex, France
} France

\author{
*: Corresponding author : Françoise Vincent-Hubert, Tel.: +33140966206 ; fax: +33140966199 \\ email address : francoise.vincent-hubert@cemagref.fr
}

\begin{abstract}
:
Highly mutagenic compounds such as some PAHs have been identified in surface waters and sediments of the Seine river estuary. Suspended particulate matter (SPM) represents a dynamic medium that may contribute to the exposure of aquatic organisms to toxic compounds in the water column of the estuary. In order to investigate major sources of mutagenic contaminants along the estuary, water samples were taken at $25 \mathrm{~m}$ downstream of the outlet of an industrial wastewatertreatment plant (WWTP). SPM samples were analyzed for their genotoxicity with two short-term tests, the Salmonella typhimurium mutagenicity assay (TA98 + S9 mix) and the comet assay in the human HepG2 cell line. Sampling sites receiving effluents from a chemical dye industry and WWTP showed the highest mutagenic potencies, followed by petrochemical industries, petroleum refinery and pulp and paper mills. These data indicate that frame-shift mutagens are present in the Seine river estuary. Furthermore, the comet assay revealed the presence of compounds that were genotoxic for human hepatocytes (HepG2 cells). We also observed a high level of mutagenic potency in the sediment of the lower estuary $\left(3 \times 10^{4}\right.$ revertants $\left./ \mathrm{g}\right)$. The source of mutagenic and genotoxic compounds seems to be associated with various types of effluents discharged in the Seine river estuary. Both test systems resulted in the same assessment of the genotoxicity of particulate matter, except for three of the 14 samples, underlying the complementarity of bioassays.
\end{abstract}

Keywords : Ames test ; Comet assay ; Water pollution ; Effluent ; Suspended particulate matter ; Seine estuary 


\section{Introduction}

Water pollution by chemicals, as a result of massive industrialization and increasing urbanization, is a factor which threatens the preservation of aquatic ecosystems and also human health. River waters in Europe, Asia, South and North America show a strong contamination with chemical mutagens $[1,2]$. These rivers are reported to be contaminated with partially treated wastewaters from urban, agricultural and industrial sources. In France, the available data on genotoxicity of river waters in estuaries and urban areas are limited, with the exception of hospital effluents [3] and aquatic sediments from the Seine estuary $[4,5]$. The Seine river basin is the most urbanized and industrialized river basin in France. In addition, the Seine river estuary drains an area contaminated by urban and industrial activities located close to the cities of Rouen and Le Havre. Industrial activities are mostly petroleum refineries, paper industries and petrochemical industries. A large variety of pollutants, such as Polycyclic Aromatic Hydrocarbons (PAHs), Polychlorobiphenyls (PCBs) and heavy metals, were quantified in the Seine river estuary $[5,6]$. The genotoxicity of the Seine river estuary sediment has been previously reported, underlying the mutagenic hazard for aquatic organisms [5].

Hydrophobic toxic compounds, including many genotoxic agents, are mostly adsorbed to suspended particulate matter (SPM) which are highly concentrated in industrial effluents $[7,8]$. After sedimentation, SPM are then accumulated in the sediment and contribute to its genotoxicity. Compared to sediment, the suspended particulate matter contains both short-living and persistent pollutants; this dynamic media may contribute to the exposure of aquatic organisms to toxic compounds in the water column. Despite the presence of high $\mathrm{K}_{\mathrm{ow}}$ substances and high concentrations of suspended particulate matter in effluents, few researchers have investigated the genotoxicity of substances adsorbed to effluent particulate matter [8-11]. Therefore, the measurement of SPM genotoxicity is very helpful in understanding the source of water genotoxicity. 
A large number of different assays have been recommended to assess the presence of genotoxic contaminants in wastewater and industrial effluents [1]. Much of published surface water mutagenicity studies employed the Salmonella mutagenicity test with strains TA 98 and/or TA100, with and without metabolic activation [1]. The different responses of the Salmonella strains can provide information on the classes of mutagens present in the water. Using mutagenic potency values, Houk categorized effluents, collected just prior to discharge in the waterways, from low to high genotoxicity according to the industrial sources [12-14].

The most commonly used assay to measure DNA lesions (strand breaks, alkali labile sites and cross-links) is the comet assay. The comet assay, also known as the single-cell gel electrophoresis (SCGE) assay, was originally introduced by Ostling and Johanson [15] to measure DNA strand breaks in mammalian cells induced by radiation. This assay, which has been shown to be a rapid and reliable procedure for the quantification of DNA lesions, is now performed with various cell lines ( $\mathrm{CHO}, \mathrm{V} 79$, HepG2) for the detection of chemical genotoxicity [16] such as those caused by extracts of chlorinated drinking water on HepG2 cell line DNA [17]. The HepG2 cells have retained the activities of phase I and phase II enzymes that play a key role in the activation and detoxification of DNA reactive carcinogens. Therefore, genotoxicity assays on eukaryotic cells, such as the Hep G2 cells, are complementary to in vitro tests with bacteria and also more relevant to human risk assessment.

The aim of the present study was to identify major sources of the genotoxic/mutagenic contamination observed in the Seine river estuary. While most studies have measured genotoxicity of effluents just prior to discharge into the river, we wanted here to integrate the dispersion of SPM in the river. Therefore, water samples were collected in the waterways about 25 meters downstream of industrial or municipal effluents. SPM genotoxicity has been analyzed with two short-term tests to compare their sensitivity, the Salmonella mutagenicity assay (TA98 strain with S9 mix) and the comet assay on HepG2 cell line. To our knowledge, genotoxicity assessment of estuarine waters has not been 
performed in France before this study. These data will also serve as a reference for ongoing studies on water genotoxicity assessment in the Seine river basin. 


\section{Materials \& Methods}

\subsection{Chemicals and media}

Dulbecco's modified Eagle's medium (DMEM), fetal calf serum and antibiotics (penicillin, streptomycin), phosphate-buffered saline without $\mathrm{Ca2}+$ and $\mathrm{Mg} 2+$ (PBS) and Trypsin (0.05\%)-EDTA $(0.02 \%)$ solution were obtained from Gibco Laboratories (Cergy-Pontoise, France). Trypan-blue $(0.5 \% \mathrm{w} / \mathrm{v})$, Benzo[a]Pyrene $(\mathrm{B}[\mathrm{a}] \mathrm{P})$ and dimethylsulfoxide (DMSO) were purchased from Sigma (France).

\subsection{Study sites and water sample collection}

Water samples were collected in the Seine river estuary. The sampling sites are presented in Figure 1. They were chosen based on a previous study on PAHs distribution [6]. The river site located at the dam of Poses (E1) is considered as the reference site of the estuary. For effluents, the water was collected $25 \mathrm{~m}$ downstream the effluent outlet. The sediment sample was collected at Tancarville in the lower estuary. Samples of suspended particulate matter (SPM) were isolated by filtration of 40 liters of water through pre-combusted GF/F Whatman glass fiber filters $(0.7 \mu \mathrm{m})$ as previously described [6]. Each filter was wrapped in aluminium foil and stored at $-18^{\circ} \mathrm{C}$ until analysis in the lab oratory.

Sediment $(2 \mathrm{~g})$ and filter containing the SPM was extracted three times by ultrasonication using dichloromethane/methanol $(3: 1 \mathrm{v} / \mathrm{v})$ [6]. The extracts were reduced to $2 \mathrm{ml}$ using a rotary evaporator, transferred to small vials, evaporated to near dryness with a gentle stream of nitrogen gas and then resuspended in dimethylsulfoxide (DMSO) for genotoxicity testing. The SPM and the sediment were analyzed for their mutagenic and genotoxic activity. 


\subsection{Salmonella mutagenicity assay - Ames test}

The Salmonella mutagenicity assay was performed on filtered extracts, using the TA 98 strain (his D3052, rfa, uvrB, pKM101) with S9 mix for detecting frameshift mutagens according to the direct plate incorporation method [18]. To assess the cytotoxicity of the samples to the bacteria, three dose-levels of each sample were tested in TA98 strain with S9 mix. Samples, negative (DMSO, $200 \mu \mathrm{g} /$ plate) and positive (2 Anthramine, $2 \mu \mathrm{g} /$ plate) controls were pre-incubated with S9 mix (Molecular Toxicology, Inc., Annapolis. MD 21401, USA). Three plates were carried out per sample. Revertants were scored with an automatic counter (Artek Counter, OSI). The evaluation criteria was as follows: a two-fold increase in the number of revertants compared with the negative control (1\% DMSO) was considered as mutagenic [18]. As we did not have enough samples to perform a dose response curve, we plot the negative control and the tested dose; then we have estimated the mutagenic potency as follows: $y=a^{*} x+b$, where:

$y=$ number of revertants of the tested dose

$b=$ number of revertants in the negative control

$\mathrm{a}=$ mutagenic potency of the tested dose (in liter equivalent or $\mathrm{g}$ of particulate material) $\mathrm{X}=$ volume (in liter) or weight (in gram) of the tested dose

\subsection{Cell culture and treatment}

HepG2 cells (ATCC HB 8065) were obtained from the American Type Culture Collection (Biovalley, Conches, France). The cells were grown in DMEM supplemented with $10 \%$ foetal calf serum and antibiotics (1\% penicillin-streptomycin) and maintained at $37^{\circ} \mathrm{C}$ in a humidified atmosphere containing $5 \% \mathrm{CO}_{2}$. The cells were subcultured every 4 days and the medium was changed every 2 days. Routine monitoring showed the HepG2 cells to be mycoplasma-free (Mycoplasma detection kit, Biovalley, Marne-la-Vallée, France). The HepG2 cells were sampled at 100.000 cells/35 mm diameter Petri dish containing $2 \mathrm{ml}$ of 
culture medium. $24 \mathrm{~h}$ after seeding, cells were treated for $24 \mathrm{~h}$ with various concentrations of SPM extracts or B[a]P dissolved in $1 \%$ DMSO. Cytotoxicity test using trypan blue was performed for each concentration of the tested compound. All experiments were performed in duplicate for each tested concentration.

\subsection{Comet assay}

The comet assay was performed according to Singh et al. [19] with minor modifications. After the treatment, $100 \mu \mathrm{l}$ of cell suspension in $0.55 \%$ Low Melting Point agarose was spread onto microscope slides precoated with $0.5 \%$ normal melting point agarose. For each sample, two slides were prepared from the same aliquot. The cells were lysed for $1 \mathrm{~h}$ at $15^{\circ} \mathrm{C}$ in the dark in a glacial lysis solution $(2.5 \mathrm{M} \mathrm{NaCl}, 100 \mathrm{mM}$ EDTA, $10 \mathrm{mM}$ Tris $\mathrm{pH} 7.5,1 \% \mathrm{~N}$ sarcosinate, $10 \%$ DMSO, $1 \%$ triton $\mathrm{x}-100, \mathrm{pH} 10)$. DNA unwinding was performed in fresh alkaline buffer $(0.3 \mathrm{M} \mathrm{NaOH}, 1 \mathrm{mM}$ EDTA, $\mathrm{pH} 13)$ for $35 \mathrm{~min}$ at $17^{\circ} \mathrm{C}$ in the dark. DNA migration was performed with the same buffer for $20 \mathrm{~min}$ at $23 \mathrm{~V}$ and $300 \mathrm{~mA}$. After electrophoresis, the gels were neutralized by rinsing three times with buffer (Tris $0.4 \mathrm{M} \mathrm{pH}$ 7.5). The DNA was stained with ethydium bromide $(8 \mu \mathrm{g} / \mathrm{ml})$ and the slides were then stored in a wet box for $24 \mathrm{~h}$ at $4^{\circ} \mathrm{C}$ in the dark.

The slides were examined under a fluorescence microscope (Olympus BX60) (excitation filter 510-560 nm, barrier filter of $590 \mathrm{~nm}$ ) using a 40X objective. Image analysis was performed using the Komet IV software (Kinetic Imaging, Liverpool, UK). Fifty individual nucleus/slides and two slides/concentration were analysed. The DNA damage was expressed as Olive Tail Moment (OTM, arbitrary units), calculated as follow: OTM=(Tail Mean - Head Mean)* Tail\%DNA/100._We have checked that the treatment of HepG2 cells with $1 \%$ DMSO was not genotoxic (data not shown). We observed that whatever the time of treatment (4h or $24 \mathrm{~h}$ ), SPM extracts induced a dose-dependent increase of OTM (data not shown). 


\subsection{Statistical analysis}

The Shapiro test was used to verify the normality of the variance of the comet data. The nonparametric Wilcoxon test was performed to evaluate any significant differences between control and treated samples. Three levels were considered significant: $p<0.05\left(^{*}\right), p<0.01\left(^{* *}\right)$ and $\left.p<0.001{ }^{(* *}\right)$. All statistical analysis were performed with $R$ software. 


\section{Results \& Discussion}

The present study has been carried out in order to investigate major sources of genotoxicity in the Seine river estuary with two short-term tests. We focused here on particulate matter extracts, since a substantial fraction of the genotoxicity is adsorbed to SPM [10]. In order to integrate the dispersion of the SPM into the river, we collected water samples $25 \mathrm{~m}$ downstream the outlet of the effluents. Spot sampling of water on industrial sites was more convenient than using particle "traps". The flow rate was $386 \mathrm{~m}^{3} / \mathrm{s}$, which correspond to a low flow rate. The concentration of SPM that we measured ranged between $3.6 \mathrm{mg} / \mathrm{L}$ and $109.7 \mathrm{mg} / \mathrm{L}$ with three samples, E3, E5 and E7, having a smaller concentrations (Table 1).

\subsection{Mutagenicity of SPM}

We observed that $11 / 14$ samples (SPM and sediment) were mutagenic in the Ames test (TA98+S9 mix). Responses were from 2 to 21 times greater the negative control (Table 2). These results indicate the presence of frame-shift mutagens in the SPM extracts. Samples E4, E9 and E12 did not induce mutagenic effect under the testing conditions. As many published studies on this type of environmental samples are positive with the TA98 [1,20,21], we decided to chose the TA98 strain in priority. The choice of added S9 is justified by the presence of dissolved PAHs as noticed in many studies $[5,6]$. If we had had more materials, we would have tested the samples on TA100 and YG1041 with and without S9, however the YG1041 strain is more specific of nitroarenes and aromatic amine compounds, chemical compounds not yet identified in the Seine estuary.

In order to compare the mutagenicity of SPM extracts, we estimated the potency of each sample and expressed it in number of revertants per g of SPM (rev/g of SPM) (Table 3). We noticed that SPM from the chemical dye industry effluent (E5) was the most 
mutagenic of all the tested effluents; E5 was half the mutagenic potency of the sediment at Tancarville, followed by the WWTP (E7) and the petrochemical industry (E3). SPM from La Bouille (E10), a river site impacted by various types of industries and by the municipal activities of Rouen city, had a mutagenic potency similar to SPM from petrochemical industry (E3. Despite of the dispersion of contaminants in the river La Bouille, its estimated mutagenic potency measured several kilometers downstream emission sites, was similar to the estimated mutagenic potency of a petrochemical effluent. The two other river sites, Poses and a site upstream Rouen city (E6), had lower potencies. We also noticed that samples with low SPM concentration (between $12 \mathrm{mg} / \mathrm{L}$ and $17.6 \mathrm{mg} / \mathrm{L}$ ) were the most mutagenic ones (E5 and E7). Conversely, SPM from E9 and E12 were negative in both system tests in spite of their high SPM concentration. It seems that as the concentration of SPM increases, the genotoxic potency declines, suggesting that the sorption of genotoxic compounds depends upon the SPM concentration, as reported earlier [9]. In that study, White et al. have determined that the percent of organic genotoxins adsorbed to effluent SPM ranges between $2.3 \%$ to $99.8 \%$, depending on both the sorption partition coefficient and the concentration of available particulate matter.

As expected, the sediment collected at Tancarville, the lower part of the estuary, presented the highest mutagenic potency $\left(29.10^{3} \mathrm{rev} / \mathrm{g}\right)$ (Table 3), suggesting the transfer and accumulation of mutagenic particulate matters coming from effluents located in the upper estuary. This value is similar to the one found in Santos estuary sediment (Brazil) with $31.10^{3}$ rev/g in TA98 +S9 [20] and higher than in Nagara River (Japan) [22] or another French site in the Provence region (Berre Lagoon) (248 rev/g in TA98 + S9) [4]. However, this value is lower than those obtained at severely contaminated sites, as for example in Hamilton harbour (Lake Ontarion, Canada) with $10^{5} \mathrm{rev} / \mathrm{g}$ TA98 in the PAH-containing fraction [23,24].

We also estimated the potency of effluents and river water and expressed them in revertants per liter equivalent of original volume extracted (Fig.2). However, we considered only the particulate fraction of water as filtered water was not analyzed, so we can not directly compare our data with the classification of Houk [13]. Indeed Houk's classification 
was based on water effluents collected just prior to discharge into the environment while in our study, river water samples were collected downstream the effluent outlets. Moreover, Houk's classification included the mutagenicity of both particulate and dissolved phase, while only the particulate phase was considered in our study. However, we noticed that our samples presented low mutagenic potencies, ranging from 3.7 to 239 revertants/L (Fig.2). E5 sample, a chemical dye industry, showed the highest mutagenic potency (239 revertants/L) which is about 5 times the WWTP (E7) (36 rev/L). It is interesting to note that E5 mutagenic potency is similar to mutagenic potency of Cristais water in Brazil, a river contaminated by dye industry effluents [21].

For various reasons, the mutagenic potency of SPM from the Seine river estuary might be higher than what we measured in this study: the mutagenicity of organic compounds extracted from either filtered water, SPM or sediment are sometimes much higher in absence of S9 mix [1,2,4]; we used the standard plate incorporation method, while the sensitivity of the Ames test has been increased by the micro-suspension techniques $[25,26]$; a much higher mutagenicity of the sediment and surface water is observed with the strain YG1041 than with the TA98 strain [4,27], indicating the presence of nitroarenes and aromatic amine, a class of potent mutagens which could be found in the Seine river SPM. Finally, the evaluation of mutagenicity was determined with punctual sampling. A more representative response could be obtained with passive sampling. For example, the dissolved PAHs can be sampled with the Blue rayon; in the same way, the particulate matters can be collected with sediment traps; both methods were used with success in rivers and estuaries [21,28,29].

\subsection{Genotoxicity of SPM}

The genotoxicity of SPM extracts was determined with the alkaline comet assay after a $24 \mathrm{hr}$ treatment of HepG2 cells. Our data revealed that 12/14 samples (SPM and sediment 
extracts) elicited a significant increase of OTM compared with control cells, indicating that micro-pollutants adsorbed on SPM extracts are genotoxic for human hepatocytes; E9 and E13 SPM extracts were not genotoxic (Table 2).

The normalization of the OTM values per $g$ of SPM allowed the comparison of genotoxic samples (Table 3): similar to the Salmonella mutagenicity data, the sediment of Tancarville had the highest genotoxic potency, followed by E7, E5 and E6. The site of Poses, considered as the reference site of the estuary, and E12, had the lower genotoxic potency. The normalization of the OTM value per liter of water gave a quite similar ranking except that the sample from the river site upstream Rouen (E6) had the highest genotoxic potency (Fig.2), followed by samples from the WWTP (E7), pulp and paper mill industries (E2 and E4), chemical dye (E5) and petrochemical industries (E11). In spite of the dispersion of SPM in the river, the genotoxic potencies of these sites were higher than the OTM of the higher concentration of $B[a] P$ tested in this study (data not shown).

Similarly to the Ames test data, these results suggested that the genotoxic and mutagenic SPM from the upper estuary probably contribute to the genotoxic and mutagenic activities detected at Tancarville, $100 \mathrm{~km}$ lower in the river. Therefore, the sediment sampled at the mouth of the estuary constitutes a pool of genotoxic chemicals.

Compared to the Ames test, the comet assay provides a completely different aspect of the genotoxicity as the DNA strand breaks measured with this assay are reparable DNA lesions; some of them may lead to mutations. The comet assay is frequently used for the measurement of surface water or sediment genotoxicity on various cell lines for ecotoxicological purposes $[4,30]$ or human risk assessment (e.g. safety assessment of drinking water, identification of the source of mutagenicity in river water [31,32]. The DNAdamaging activity of SPM detected on HepG2 cell lines revealed the presence of progenotoxic compounds adsorbed on SPM, as the HepG2 cells retains the capacity of metabolic activation. These results, as for the Ames test data, suggest the involvement of PAHs. Moreover, PAHs were detected on the SPM and sediment sampled in the Seine estuary [5,6]. Carcinogenic PAHs are genotoxic after being metabolized by Cytochrome 
P450 enzymes or by peroxidases. Some of their metabolites acquire electrophilic properties, allowing the formation of bulky DNA adducts due to covalent binding to DNA bases. DNA strand breaks might be due to the DNA repair of PAHs induced DNA adducts, as it has been shown previously on HepG2 cells treated either with various PAHs or with Benzo[a]pyrene solely [33-35]. Moreover, Cachot et al. [5] have shown that the PCB and PAH fractions of sediments were the more genotoxic using the SOS chromotest.

\subsection{Comparison of mutagenicity and genotoxicity}

Genotoxicity end-points measured with these two short-term tests are different: the Ames test with TA98 strain detected frame-shift mutagens and the alkaline comet assay revealed both genotoxicity (single and double strand break) and DNA repair of various DNA lesions such as bulky DNA adducts and DNA oxidation. Moreover, one test was performed on bacteria and the other one on human cells, suggesting a difference of sensitivity of these biological systems towards metabolized contaminants. These two short-term tests (Table 3 and Fig. 2) revealed a similar tendency except for E4, E12 and E13. These tests are complementary as they show that some SPM samples (E4, E12, E13) are either genotoxic or mutagenic.

We found that the sediment sampled at Tancarville is highly mutagenic and Cachot et al. found a moderate genotoxicity at Quilleboeuf-sur-Seine, a site located $10 \mathrm{~km}$ upstream Tancarville. These data underline that the evaluation of the genotoxic potency of sediments could be related to the bacterial short-term tests used, as previously reported with particulate river material with the umu-test and the Ames test [11] or with sediment [2].

In conclusion, this preliminary study allowed the detection of genotoxic and mutagenic SPM, in spite of the dispersion of SPM in the river. Sampling sites receiving effluents from chemical 
dye industry and WWTP showed the highest mutagenic potencies. SPM from the upper estuary probably contributes to the genotoxic activity of the sediment. The identification of mutagenic compounds should be investigated to discover chemicals responsible for the mutagenicity of the SPM.

\section{Conflict of interest}

None

\section{Acknowledgements}

We thank Dr. Gisela Umbuzeiro for efficient suggestions concerning this manuscript. We are grateful to Laetitia Besseau for technical assistance. This study was supported by the multidisciplinary Seine-Aval research program. 


\section{References}

[1] T. Ohe, T. Watanabe and K. Wakabayashi Mutagens in surface waters: A review, Mutation Research Reviews in Mutation Research 567 (2004) 109-149.

[2] G. Chen and P.A. White The mutagenic hazards of aquatic sediments: A review, Mutation Research Reviews in Mutation Research 567 (2004) 151-225.

[3] B. Jolibois and M. Guerbet Hospital wastewater genotoxicity, Annals of Occupational Hygiene 50 (2006) 189-196.

[4] A. Aouadene, C. Di Giorgio, L. Sarrazin, X. Moreau, L. De Jong, F. Garcia, A. Thiery, A. Botta and M. De Méo Evaluation of the genotoxicity of river sediments from industrialized and unaffected areas using a battery of short-term bioassays, Environmental and Molecular Mutagenesis 49 (2008) 283-299.

[5] J. Cachot, O. Geffard, S. Augagneur, S. Lacroix, K. Le Menach, L. Peluhet, J. Couteau, X. Denier, M.H. Devier, D. Pottier and H. Budzinski Evidence of genotoxicity related to high PAH content of sediments in the upper part of the Seine estuary (Normandy, France), Aquatic Toxicology 79 (2006) 257-267.

[6] M.B. Fernandes, M.A. Sicre, A. Boireau and J. Tronczynski Polyaromatic hydrocarbon (PAH) distributions in the Seine River and its estuary, Marine Pollution Bulletin 34 (1997) 857-867.

[7] S.W. Karickhoff, D.S. Brown and T.A. Scott Sorption of hydrophobic pollutants on natural sediments, Water Research 13 (1979) 241-248.

[8] P.A. White, J.B. Rasmussen and C. Blaise Genotoxic substances in the St. Lawrence system I: Industrial genotoxins sorbed to particulate matter in the St. Lawrence, St. Maurice, and Saguenay Rivers, Canada, Environmental Toxicology and Chemistry 17 (1998) 286-303.

[9] P.A. White, J.B. Rasmussen and C. Biaise Sorption of organic genotoxins to particulate matter in industrial effluents, Environmental and Molecular Mutagenesis 27 (1996a) 140-151.

[10] P.A. White, J.B. Rasmussen and C. Blaise Comparing the presence, potency, and potential hazard of genotoxins extracted from a broad range of industrial effluents, Environmental and Molecular Mutagenesis 27 (1996b) 116-139.

[11] H.H. Vahl, L. Karbe and J. Westendorf Genotoxicity assessment of suspended particulate matter in the elbe river: Comparison of Salmonella microsome test, arabinose resistance test, and umu-test, Mutation Research - Genetic Toxicology and Environmental Mutagenesis 394 (1997) 81-93.

[12] L.D. Claxton, G.A. De Umbuzeiro and D.M. DeMarini The salmonella mutagenicity assay: The stethoscope of genetic toxicology for the 21st century, Environmental Health Perspectives 118 (2010) $1515-1522$.

[13] V.S. Houk The genotoxicity of industrial wastes and effluents: A review, Mutation Research - Reviews in Mutation Research 277 (1992) 91-138.

[14] L.D. Claxton, V.S. Houk and T.J. Hughes Genotoxicity of industrial wastes and effluents, Mutation Research - Reviews in Mutation Research 410 (1998) 237-243.

[15] O. Ostling and K.J. Johanson Microelectrophoretic study of radiation-induced DNA damages in individual mammalian cells, Biochemical and Biophysical Research Communications 123 (1984) 291298.

[16] Y. Miyamae, K. Iwasaki, N. Kinae, S. Tsuda, M. Murakami, M. Tanaka and Y.F. Sasaki Detection of DNA lesions induced by chemical mutagens using the single-cell gel electrophoresis (Comet) assay. 2. Relationship between DNA migration and alkaline condition, Mutation Research - Genetic Toxicology and Environmental Mutagenesis 393 (1997) 107-113.

[17] W.Q. Lu, D. Chen, X.J. Wu, A.L. Liu, H. Liu, J.J. Wu and V. Mersch-Sundermann DNA damage caused by extracts of chlorinated drinking water in human derived liver cells (HepG2), Toxicology 198 (2004) 351-357.

[18] D.M. Maron and B.N. Ames Revised methods for the Salmonella mutagenicity test, Mutation Research 113 (1983) 173-215.

[19] N.P. Singh, M.T. McCoy, R.R. Tice and E.L. Schneider A Simple Technique for Quantitation of LowLevels of DNA Damage in Individual Cells, Experimental Cell Research 175 (1988) 184-191.

[20] G.D.A. Umbuzeiro, F. Kummrow, D.A. Roubicek and M.Y. Tominaga Evaluation of the water genotoxicity from Santos Estuary (Brazil) in relation to the sediment contamination and effluent discharges, Environment International 32 (2006) 359-364.

[21] G. Umbuzeiro, D.A. Roubicek, C.M. Rech, M.I.Z. Sato and L.D. Claxton Investigating the sources of the mutagenic activity found in a river using the Salmonella assay and different water extraction procedures, Chemosphere 54 (2004) 1589-1597. 
[22] T. Sato, T. Momma and Y. Ose Mutagenicity of Nagara River sediment, Mutation Research 118 (1983) 257-267.

[23] C.H. Marvin, B.E. McCarry, J. Villella, L.M. Allan and D.W. Bryant Chemical and biological profiles of sediments as indicators of sources of contamination in hamilton harbour. Part II: Bioassay-directed fractionation using the Ames Salmonella/microsome assay, Chemosphere 41 (2000) 989-999.

[24] C.H. Marvin, L. Allan, B.E. McCarry and D.W. Bryant Chemico/biological investigation of contaminated sediment from the Hamilton Harbour area of Western Lake Ontario, Environmental and Molecular Mutagenesis 22 (1993) 61-70.

[25] N.Y. Kado, D. Langley and E. Eisenstadt A simple modification of the Salmonella liquid-incubation assay. Increased sensitivity for detecting mutagens in human urine, Mutation Research 121 (1983) 2532.

[26] M. De Méo, M. Laget, C. Di Giorgio, H. Guiraud, A. Botta, M. Castegnaro and G. Duménil Optimization of the Salmonella/mammalian microsome assay for urine mutagenesis by experimental designs, Mutation Research - Reviews in Genetic Toxicology 340 (1995) 51-65.

[27] T. Watanabe, T. Ohe and T. Hirayama Occurrence and origin of mutagenicity in soil and water environment, Environmental sciences : an international journal of environmental physiology and toxicology. 12 (2005) 325-346.

[28] D. Broman, C. Naf and U. Rannug Mutagenic effect of extracts from particulate matter collected with sediment traps in the archipelago of Stockholm and the open Northern Baltic, Bulletin of Environmental Contamination and Toxicology 53 (1994) 669-674.

[29] H. Sakamoto, T. Ohe, T. Hayatsu and H. Hayatsu Evaluation of blue-chitin column, blue-rayon hanging, and XAD-resin column techniques for concentrating mutagens from two Japanese rivers, Mutation Research - Genetic Toxicology 371 (1996) 79-85.

[30] S. Keiter, A. Rastall, T. Kosmehl, K. Wurm, L. Erdinger, T. Braunbeck and H. Hollert Ecotoxicological assessment of sediment, suspended matter and water samples in the upper Danube River: A pilot study in search for the causes for the decline of fish catches, Environmental Science and Pollution Research 13 (2006) 308-319.

[31] A. Buschini, P. Carboni, S. Frigerio, M. Furlini, L. Marabini, S. Monarca, P. Poli, S. Radice and C. Rossi Genotoxicity and cytotoxicity assessment in lake drinking water produced in a treatment plant, Mutagenesis 19 (2004) 341-347.

[32] J.H. Kwon, H.K. Lee, J.W. Kwon, K. Kim, E. Park, M.H. Kang and Y.H. Kim Mutagenic activity of river water from a river near textile industrial complex in Korea, Environmental Monitoring and Assessment 142 (2008) 289-296.

[33] S.H. Cherng, S.L. Hsu, J.L. Yang, C.T.R. Yu and H. Lee Suppressive effect of 1-nitropyrene on benzo[a]pyrene-induced CYP1A1 protein expression in HepG2 cells, Toxicology Letters 161 (2006) 236-243.

[34] Y.C.M. Staal, M.H.M. van Herwijnen, F.J. van Schooten and J.H.M. van Delft Modulation of gene expression and DNA adduct formation in HepG2 cells by polycyclic aromatic hydrocarbons with different carcinogenic potencies, Carcinogenesis 27 (2006) 646-655.

[35] C. Marie, A. Maître, T. Douki, M. Gateau, A. Tarantini, P. Guiraud, A. Favier and J.L. Ravanat Influence of the metabolic properties of human cells on the kinetic of formation of the major benzo[a]pyrene DNA adducts, Journal of Applied Toxicology 28 (2008) 579-590. 
Table 1: Sampling site characteristics. The sampling sites are $25 \mathrm{~m}$ downstream industrial or WWTP effluents, except E1, E6, E10 and E12. E1 (Poses), E6 (Upstream Rouen), E10 (La Bouille) and E12 (Commerce River) are four river sites. Commerce River is a tributary of the Seine River. The site of Poses (E1) is considered as the estuarine reference site. Other sites are directly under the influence of effluents. Site locations are illustrated on figure 1. The concentrations of suspended particulate matter (SPM) are reported for each site.

\begin{tabular}{ccc}
\hline Sample sites & characteristics & SPM (dry mg/l) \\
\hline E1 & - & 56.4 \\
E2 & Pulp and paper & 55.7 \\
E3 & Petrochemical & 3.6 \\
E4 & Pulp and paper & 60.3 \\
E5 & Chemical dye & 17.6 \\
E6 & - & 40.4 \\
E7 & Wastewater treatment plant & 12.04 \\
E8 & Petroleum refinery & 25.9 \\
E9 & Pulp and paper mill & 95.6 \\
E10 & - & 30.9 \\
E11 & Petrochemical & 109.7 \\
E12 & - & 98,7 \\
E13 & Petroleum refinery & 95.04 \\
\hline
\end{tabular}


Table 2: Screening analysis of the mutagenicity and genotoxicity of suspended particulate matters (SPM) and sediment samples from the Seine estuary. The mutagenicity was measured with the Salmonella/microsome assay using TA98 strain + S9 mix, the genotoxicity was measured with the comet assay after a $24 \mathrm{~h}$ treatment of HepG2 cells with SPM or sediment organic extracts. The sediment was analysed only on the site of Tancarville. Other sites are river sites. Ratio $=$ number of revertants per sample/number of revertants per vehicule (DMSO). 2 Anthramine and $\mathrm{BaP}$ are positive controls.

*** $p<0.001$ : significantly different from control cells.

\begin{tabular}{|c|c|c|c|c|}
\hline Site & $\begin{array}{c}\text { Mean of } \\
\text { revertants/plate } \pm S D\end{array}$ & ratio & $\begin{array}{l}\text { Mutagenic } \\
\text { activity }\end{array}$ & OTM/plate \\
\hline E1 & $80 \pm 8$ & 5.1 & + & $5.8 \pm 0.6^{* \star *}$ \\
\hline E2 & $63 \pm 9$ & 4.1 & + & $11.2 \pm 0.54^{* * *}$ \\
\hline E3 & $44 \pm 8$ & 2.9 & + & $8.2 \pm 0.8^{* * *}$ \\
\hline E4 & $27 \pm 7$ & 1.8 & - & $6.7 \pm 0.3^{* \star *}$ \\
\hline E5 & $315 \pm 37$ & 20.6 & + & $8.4 \pm 0.37^{* * *}$ \\
\hline E6 & $31 \pm 7$ & 2 & + & $13.4 \pm 0.548^{* * *}$ \\
\hline E7 & 38 & 2.5 & + & $11.4 \pm 0.548^{* * *}$ \\
\hline E8 & $36 \pm 3$ & 2.4 & + & $11 \pm 0.45^{* * *}$ \\
\hline E9 & $21 \pm 4$ & 1.4 & - & $3.9 \pm 0.3$ \\
\hline E10 & $125 \pm 16$ & 7.9 & + & $6 \pm 0.3^{* * *}$ \\
\hline E11 & $145 \pm 22$ & 9.3 & + & $14.5 \pm 2^{* * *}$ \\
\hline E12 & $23 \pm 5$ & 1.5 & - & $5.7 \pm 0.48^{* * *}$ \\
\hline E13 & $122 \pm 19$ & 7.8 & + & $3.3 \pm 0.19$ \\
\hline Sediment of Tancarville & $118 \pm 10$ & 7.6 & + & $11.4 \pm 0.7^{* \star *}$ \\
\hline 2 Anthramine & $676 \pm 104$ & 43.1 & + & nd \\
\hline $\mathrm{BaP}(10 \mu \mathrm{M})$ & & & & $10.3 \pm 0.5$ \\
\hline DMSO 1\% & $16 \pm 1$ & 1 & - & $2.9 \pm 0.2$ \\
\hline Control & & & & $2.7 \pm 0.2$ \\
\hline
\end{tabular}


Table 3: Mutagenic and genotoxic potency per gram of SPM or sediment. The mutagenic potencies and the genotoxic potencies per gram of SPM or sediment were calculated as described in the materials and methods section. Ames test: number of revertants per g of SPM or sediment; comet assay: OTM per g of SPM or sediment. Poses (E1), upstream Rouen (E6), La Bouille (E10) and Commerce River (E12) are four river sites. Commerce River is a tributary of the Seine River. The site of Poses is considered as the estuarine reference site. Other sites are directly under the influence of effluents (Table 1). Tancarville sediment shows the highest level of chemical contamination in the estuary.

* The sediment was analysed only on the site of Tancarville.

\begin{tabular}{|l|cc|}
\hline & \multicolumn{2}{|l|}{$\begin{array}{l}\text { Mutagenic or genotoxic potencies } \\
\text { per gram of SPM or sediment* }\end{array}$} \\
\hline Sites & Ames test (TA 98 + S9) & Comet assay on HepG2 cells \\
E1 & 289.46 & 81.79 \\
E2 & 465.35 & 815.66 \\
E3 & 1018.18 & 751.45 \\
E4 & - & 495.35 \\
E5 & 13590.91 & 1988.97 \\
E6 & 150.00 & 1657.14 \\
E7 & 2968.96 & 4589.19 \\
E8 & 153.73 & 492.93 \\
E10 & 1358.93 & 271.10 \\
E11 & 439.79 & 283.75 \\
E12 & - & 22.92 \\
E13 & 444.94 & - \\
\cline { 1 - 2 } Tancarville sediment & 28598.13 & 75095.33 \\
\hline
\end{tabular}




\section{Figures}

Figure 1: Location of sampling sites. The Seine estuary extends over $153 \mathrm{Km}$ with a freshwater part from the Dam of Poses to Caudebec and saltwater part from Caudebec to Honfleur. Effluents are located in the region of Rouen, except two sites (E12, E13) located downstream of Vieux Port. Effluents were numbered: E2, E3, E4, E5, E7, E8, E9, E11 and E13; for these sites, water was collected 25 m downstream the outlet of effluent. Four sites correspond to river water: E1 located downstream the dam of Poses, E6 upstream of Rouen city, E10 located at La Bouille, and E12 on the Commerce River. Sediment has been collected at Tancarville a site showing the highest level of chemical contamination in the estuary.

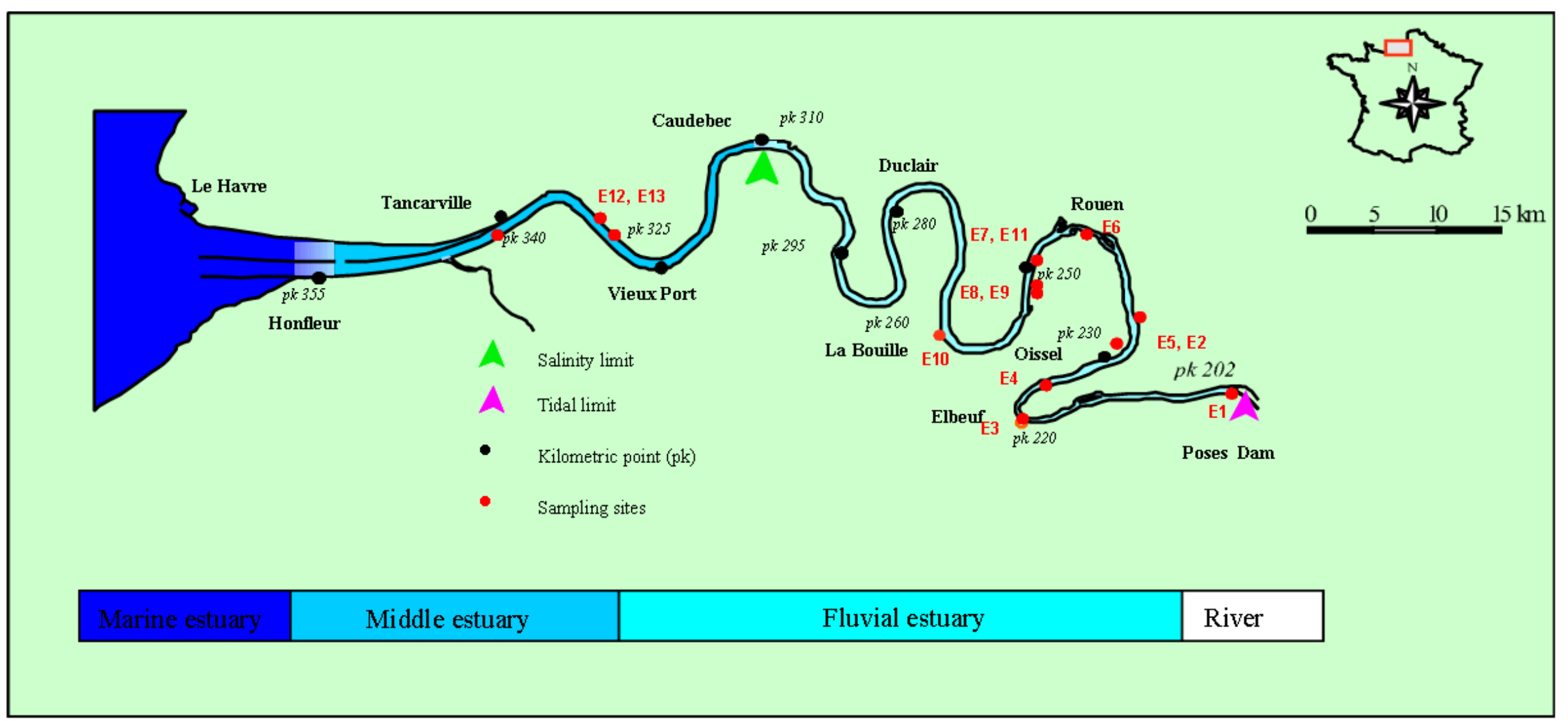


Figure 2: Genotoxic and mutagenic potency per liter equivalent of Seine river water. The mutagenic and the genotoxic potencies per liter equivalent were calculated as described in the materials and methods section. For the mutagenic potency, the values are expressed in number of revertants per liter equivalent of water. For the comet assay, the values are expressed in OTM per liter equivalent of water. Poses, upstream Rouen, La Bouille and E12 are river sites. The site of Poses is considered as the estuarine reference site.

\section{$\square$ OTM/liter equivalent $\square$ revertants/liter equivalent}

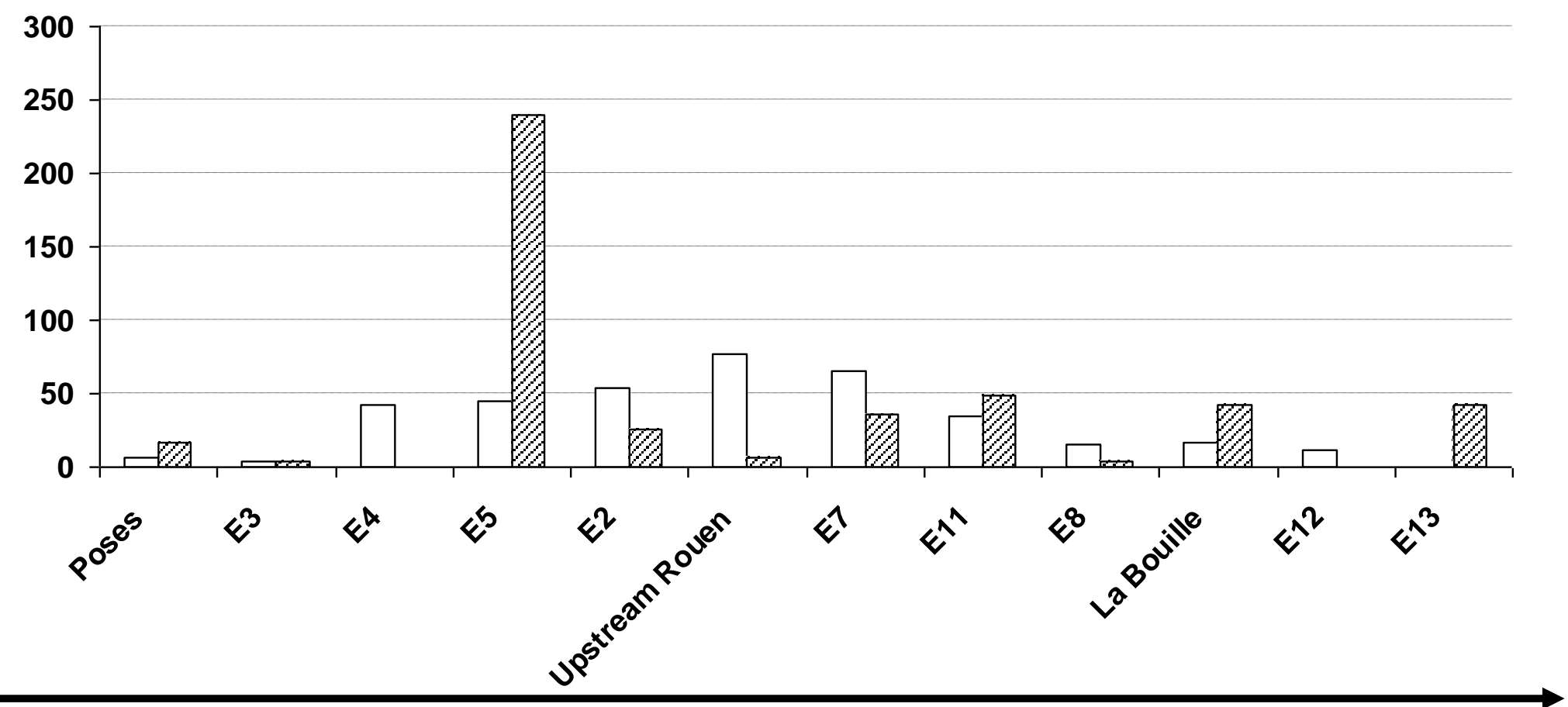

Upper estuary

Lower estuary 